\title{
Antiplasmodial Efficacy of Vernonia amygdalina in Albino Mice Infected with Plasmodium berghei
}

\author{
Olajide Joseph Afolabi* and Jimoh Lateefat Oyewole
}

Department of Biology, Federal University of Technology Akure, Nigeria

*Corresponding author: Olajide Joseph Afolab, Department of Biology, Federal University of Technology Akure, Nigeria

\begin{abstract}
Malaria is one of the world's most serious diseases caused by Plasmodium parasite. It remains the greatest cause of hospitalization and death among human parasitic infections. Over $40 \%$ of the world's population is at risk of malaria and active clinical cases due to Plasmodium falciparium. The study entitled "Antiplasmodial efficacy of Vernonia amygdalina in mice infected with Plasmodium berghei" is aimed at investigating the antiplasmodial activity of the ethanolic leaf exytract of Vernonia amygdalina in Plasmodium berghei infected mice. The study involves preparation of ethanolic extract from the leaves of Vernonia amygdalina using maceration method followed by evaporation of ethanol using rotary evaporator to get gummy residue as an extract and then determining its antiplasmodial activity in $P$. berghei NK65 strain infected mice. Twenty-six Albino mice used for the in vivo experiment were housed under the standard conditions and maintained on standard pelleted food and water. Ninety-six (96) hours (4 days) curative test in mice model was done to check the effect of the plant extract in the mice infected with $P$. berghei. The result showed average percentage parasitemia of $1.68 \pm 0.76,0.90 \pm 0.39$ and $0.41 \pm$ 0.41 with average percentage curative effect of $69.5 \%, 72 \%$ and $94 \%$ at dosage levels of 400,600 and $800 \mathrm{mg} / \mathrm{kg}$ respectively. This indicated that the antiplasmodial effect of $V$. amygdalina increases as the dosage of the extract increases. The plant extract produced significant curative effect in dose dependent manner during 96 hours of treatment. The extract showed promising curative activity against $P$. berghei. Therefore, $V$. amygdalina may be considered in malaria therapy.
\end{abstract}

\section{Keywords}

Vernonia amygdalina, Plasmodium berghei, Antiplasmodial effect

\section{Abbreviations \\ V. amydalina: Vernonia amydalina; $P$. berghei: Plasmodium berghei; Pfcrt: Plasmodium falciparum chloroquine resis- tance transporter; Pfmdr: Plasmodium falciparum multidrug}

resistance; IAMRAT: Institute of advanced Medical Research and Training; UCH: University College Hospital; PBS: Phosphate buffer saline; DNMRT: Duncan's New Multiple Range Test; SPSS: Statistical Package for Social Sciences

\section{Introduction}

Malaria is the leading parasitic disease globally and the causative agent (Plasmodium falciparum) is responsible mostly for the mortality and morbidity associated with the disease. The disease is prevalent and devastating parasitic infection globally [1]. Malaria caused about 627,000 malaria deaths worldwide and $90 \%$ of these mortalities were recorded in the African region, followed by Southeast Asia (7\%) and the Eastern Mediterranean (3\%) [2]. Death mostly associated with malaria is caused by $P$. falciparum. However, $P$. vivax is now increasingly noted to be responsible for pernicious malaria and death [2]. The World Malaria Report [3] shows that the scourge of malaria continues to strike hardest against pregnant women and young children in Africa. Scaling up efforts to reduce cases and deaths among these two populations would provide a significant boost in the fight against malaria.

Chemotherapy remains possible control measure for malaria infection and the previously effective chloroquine has substantially failed as a prophylactic and therapeutic malaria drug in many endemic countries especially in Africa, Asia and South America due to the widespread of chloroquine resistant $P$. falciparum strains with mutant alleles for chloroquine resistance transporter proteins (pfcrtT76) and multidrug resistance glycoprotein-1 (pfmdr-1Y86) [4]. However, most of these

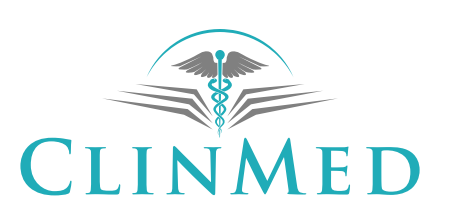

INTERNATIONAL LIBRARY
Citation: Afolabi OJ, Oyewole JL (2020) Antiplasmodial Efficacy of Vernonia amygdalina in Albino Mice Infected with Plasmodium berghei. Int J Pediatr Res 6:115. doi.org/10.23937/2469-5807/1510115 Accepted: October 20, 2020: Published: October 22, 2020

Copyright: (c) 2020 Afolabi OJ, et al. This is an open-access article distributed under the terms of the Creative Commons Attribution License, which permits unrestricted use, distribution, and reproduction in any medium, provided the original author and source are credited. 
treatments available are used in loose dosages and are currently having difficulty in administration mostly in rural areas of the developing countries due to affordability and accessibility constraints [5]. However, chloroquine still remains the drug of choice against malaria in pregnancy because it is safe and cheap to use, these qualities remain insurmountable by other antimalarial drugs [6]. The above findings have justified the need to develop strategies of restoring chloroquine efficacy and prolong its clinical utility in malaria treatment.

In the last twenty years, these strategies have been employed by pharmaceutical companies as antidepressants (e.g. fluoxetine and desipramine), antihistamines (e.g. promethazine and chlorpheniramine), calcium channels blockers (e.g. verapamil and nifedipine) and antipsychotics (e.g. chlorpromazine) to reverse chloroquine resistance by $P$. falciparum in vitro and in vivo in rodent [7] and apes malaria models [8]. In addition, apart from the obvious elevated cost of treating malaria, many of these chemo-sensitizers have multi-systemic effects, which may provoke side effects and their various dosages of chloroquine resistance reversal can be toxic [9]. For instance the work of [10] provided a scientific validity for the local use of Vernonia amygdalina for the malaria treatment in the Democratic Republic of Congo.

Vernonia amygdalina (English: Bitter leaf, Yoruba: Ewuro, Igbo: Pnugbu, Hausa: Chusardoki, Tiv: Ityuna, Ibibio: Etidot) is a perennial herb belonging to the Compositae family. The Compositae are herbs, shrubs, or less commonly trees which are the largest family of angiosperms and has approximately 1,620 genera and more than 23,600 species of flowering plants [11]. It grows majorly in tropical Africa especially in Nigeria, Zimbabwe and South Africa and it is domesticated in most parts of West Africa [12]. In addition, Tona, et al. [10]; Abosi and Raseroka [13] and Massaba [14] indicated that Vernonia amygdalina leaf extract is a promising antimalarial agent because of its ability to reduce parasitemia in malaria patient. In this regard, various dosages of Vernonia leaf extract were used to evaluate the antiplasmodial efficacies of the plant in mice infected with sensitive chloroquine Plasmodium berghei strains.

\section{Materials and Methods}

\section{Plant material and identification}

The leaves of $V$. amygdalina free of insects were obtained from FUTA South Gate, Akure, Ondo State, Nigeria during the rainy season. The plant was taken to the Department of Biology laboratory, Federal University of Technology, Akure, Ondo State; for identification.

\section{Preparation of plant extract}

The leaves were air-dried at room temperature (27 $\pm 2{ }^{\circ} \mathrm{C}$ ) for six weeks, the dried leaves were ground into coarse powder with Qasa electric blender (Model: QBL-
$1861 \mathrm{~A})$. Three hundred grams (300 g) of the powdered leaves were extracted with $1500 \mathrm{ml}$ of $96 \%$ ethanol by maceration for 72 hours. The extract was then filtered and concentrated under vacuum in a rotary evaporator $\left(78{ }^{\circ} \mathrm{C}, 450 \mathrm{RPM}\right)$ which yielded about $54 \%$ of gummy residue, as extract of plant part [15]. The extract was kept in a tightly closed bottle in a refrigerator until use for anti-malarial testing.

\section{Experimental animals}

The Swiss mice (20-25 g) that were used for this research were obtained from the Institute of Advanced Medical Research and Training, College of Medicine, University of Ibadan (IAMRAT). The mice were housed under the standard conditions and maintained on standard pelleted feed and water. The mice were allowed to acclimatize in the new environment for 4 days before they were inoculated with the parasite. The use and handling of mice was in accordance with the guideline for the care and use of experimental animals [16].

\section{Parasite inoculation}

The blood of a donor Swiss mouse infected with choroquine-sensitive Plasmodium berghei was used for inoculum preparation. The NK65 strain of $P$. berghei used was obtained from Institute of Advanced Medical Research and Training (IAMRAT), College of Medicine, University of Ibadan. Each mouse was passaged intraperitoneally with $0.2 \mathrm{ml}$ of the infected blood containing about $1 \times 10^{6} \mathrm{P}$. berghei parasitized red blood cells. The whole blood was diluted in phosphate buffer saline (PBS) before inoculation of the mice.

\section{Curative test}

Thirty-five mice were used and twenty-nine out of the thirty-five mice were injected intraperitoneally with $0.2 \mathrm{ml}$ of blood containing about $1 \times 10^{6} \mathrm{P}$. berghei infected erythrocytes on the fifth day. The infection which was confirmed by viewing the Giemsa-stained blood smear obtained from the mouse tail under the microscope was established 120 hours after passaging [17]. The animals were divided into seven groups, group 1 (negative control) containing 5 mice not infected with $P$. berghei and received no treatment; group 2 contains 5 mice infected with $P$. berghei but not treated with any drug or plant extract (positive control) while group 3 (drug treatment control) contains 5 infected mice who received daily doses of chloroquine at $10 \mathrm{mg} / \mathrm{kg}$. Group 4 which is the plant extract control contained 5 uninfected mice and also received $800 \mathrm{mg} / \mathrm{kg}$ of the ethanolic plant extract daily. Finally groups 5, 6 and 7 contain 5 mice each and received the following daily-doses of V. amygdalina leaf ethanolic extract at dosage concentrations $400 \mathrm{mg} / \mathrm{kg}, 600 \mathrm{mg} / \mathrm{kg}$ and $800 \mathrm{mg} / \mathrm{kg}$ (Table 1) for 4 days. All the doses of the extract and chloroquine were given to them orally for 96 hours. 
Table 1: Experimental plan for control and test animals.

\begin{tabular}{|l|l|l|}
\hline Groups & Experimental Plan & Remarks \\
\hline Group 1 & Were neither infected with Plasmodium berghei nor treated. & Negative control \\
\hline Group 2 & Were infected with Plasmodium berghei but not treated. & Positive control \\
\hline Group 3 & $\begin{array}{l}\text { Were infected with Plasmodium berghei and treated with } 10 \mathrm{mg} / \mathrm{kg} \text { of chloroquine } \\
\text { solution for 4 consecutive days. }\end{array}$ & Drug treatment control \\
\hline Group 4 & $\begin{array}{l}\text { Were not infected but were administered with } 800 \mathrm{mg} / \mathrm{kg} \text { body weight of Vernonia } \\
\text { amygdalina for 4 consecutive days. }\end{array}$ & Plant extract control \\
\hline Group 5,6,7 & $\begin{array}{l}\text { Were infected with Plasmodium bergheiand administered with Vernonia amygdalina } \\
\text { plant extract at 400,600, and } 800 \mathrm{mg} / \mathrm{kg} \text { body weight for 4 consecutive days. }\end{array}$ & Treatment \\
\hline
\end{tabular}

Table 2: Average percentage parasitemia obtained from the mice infected with $P$. berghei and treated with graded doses of $V$. amygdalina.

\begin{tabular}{|l|l|l|l|l|l|l|}
\hline \multicolumn{7}{|c|}{ Average Parasitemia } \\
\hline $\begin{array}{l}\text { Treatment at graded } \\
\text { doses (mg/kg) }\end{array}$ & Before & 1 & 2 & 3 & 4 & 5 \\
\hline V. amygdalina 400 & $12.09 \mathrm{c}$ & $5.50 \pm 1.64 \mathrm{~b}$ & $2.50 \pm 0.35 \mathrm{a}$ & $1.68 \pm 0.76 \mathrm{a}$ & $4.55 \pm 2.37 \mathrm{~b}$ & $10.98 \pm 6.33 \mathrm{~b}$ \\
\hline V. amygdalina 600 & $5.17 \mathrm{~b}$ & $3.20 \pm 0.73 \mathrm{ab}$ & $1.98 \pm 0.45 \mathrm{a}$ & $0.90 \pm 0.39 \mathrm{a}$ & $0.96 \pm 0.39 \mathrm{a}$ & $2.88 \pm 1.70 \mathrm{a}$ \\
\hline V. amygdalina 800 & $28.03 \mathrm{~d}$ & $6.74 \pm 1.89 \mathrm{~b}$ & $1.62 \pm 0.80 \mathrm{a}$ & $1.94 \pm 0.85 \mathrm{a}$ & $0.41 \pm 0.41 \mathrm{a}$ & $6.08 \pm 5.79 \mathrm{~b}$ \\
\hline Chloroquine & $12.75 \mathrm{c}$ & $0.88 \pm 0.44 \mathrm{a}$ & $0.06 \pm 0.30 \mathrm{a}$ & $0.00 \pm 0.00 \mathrm{a}$ & $0.00 \pm 0.00 \mathrm{a}$ & $0.00 \pm 0.00 \mathrm{a}$ \\
\hline Infected Untreated & $0.50 \mathrm{a}$ & $0.70 \pm 0.25 \mathrm{a}$ & $5.35 \pm 1.35 \mathrm{~b}$ & $13.39 \pm 6.51 \mathrm{~b}$ & $4.56 \pm 1.76 \mathrm{~b}$ & $9.50 \pm 1.76 \mathrm{~b}$ \\
\hline
\end{tabular}

\section{Determination of parasitemia}

Thick and thin smears were prepared with blood collected from the tail of each mouse every 24 hours for 4 days. The thin films were fixed with methanol and allowed to dry before it was stained with $3 \%$ Giemsa stain for 30 minutes. The films were viewed under the oil immersion objective (X100) of the light microscope to determine the parasite density. The percentage parasitemia was determined using the following formula:

$$
\% \text { Parasitaemia }=\frac{\text { Number of Infected RBC }}{\text { Total Number of RBC }} \times 100
$$

$\%$ curative $=\frac{\text { Parasitemia before treatment }- \text { Parasitemia after treatment }}{\text { Paraitenia } \text { before treatment }} \times 100$

\section{Data analysis}

The results were analyzed for statistical significance using one-way ANOVA. The mean and the level of significance for the differences between means of the data obtained were computed using Duncan's New Multiple Range Test (DNMRT) at $P<0.05$. All the statistical analyses were done using SPSS version 20.0.

\section{Results}

\section{Antiplasmodial activity of the plant extract and chloroquine}

The results showed that the percentage parasitemia increased in the mice treated with $V$. amygdalina extract at different doses of 400,600 and $800 \mathrm{mg} / \mathrm{kg}$ on day 1 of treatment; meanwhile, the percentage parasitemia of the mice treated with chloroquine at $10 \mathrm{mg} /$ $\mathrm{kg}$ did not increase compared to those treated with $V$. amygdalina extract. On day 2 the parasitemia of the mice at 400, 600 and $800 \mathrm{mg} / \mathrm{kg}$ decreased. However, optimum activity of the plant extract was recorded in all treatment groups on day 3 . At days 4 and 5 the curative test showed that there is no significant difference in the percentage parasitemia at different doses of 400 , 600 and $800 \mathrm{mg} / \mathrm{kg}$ for the mice treated with the plant extract, the infected untreated and mice treated with chloroquine at $10 \mathrm{mg} / \mathrm{kg}$ (Table 2).

Figures in column 2 is the parasitemia before treatment.

Figures with the same alphabet down the column are not significantly different $(P>0.05)$.

The results presented in Table 3 showed that mice treated with $400 \mathrm{mg} / \mathrm{kg}$ of the plant extract at day 1 ( 24 hrs) showed increase in body weight, while at days 2-4 (48-96 hrs) the mice treated with the same dose $(400$ $\mathrm{mg} / \mathrm{kg}$ ) of the plant extract experienced decrease in body weight. Similarly, mice treated with $800 \mathrm{mg} / \mathrm{kg}$ for 1-4 days (24-96 hrs) experienced decrease in body weight. However, the highest weight loss (13.3 g) was noted in mice treated with $800 \mathrm{mg} / \mathrm{kg}$ for $72 \mathrm{hrs}$ while mice treated with $400 \mathrm{mg} / \mathrm{kg}$ of the plant extract gained $0.70 \mathrm{~g}$ of body weight. Generally, weight loss was observed in all the mice except mice treated with $400 \mathrm{mg} /$ kg for 24 hrs.

\section{Percentage effectiveness of the plant extract and chloroquine at $\mathbf{2 4}$ hours interval}

The percentage effectiveness results presented in Table 4 showed that chloroquine, the standard drug cleared the parasite (P. berghei) by $100 \%$ at $10 \mathrm{mg} / \mathrm{kg}$ 
Table 3: Average percentage weight loss or gain of the Albino mice after treatment.

\begin{tabular}{|c|c|c|c|c|c|}
\hline $\begin{array}{l}\text { Treatment at } 24 \\
\text { hours interval }\end{array}$ & $\begin{array}{l}\text { Percentage } \\
\text { Parasitemia (\%) }\end{array}$ & $\begin{array}{l}\text { Weight before } \\
\text { treatment }(\mathrm{g})\end{array}$ & $\begin{array}{l}\text { Weight after } \\
\text { treatment }(g)\end{array}$ & $\begin{array}{l}\text { Weight loss/ } \\
\text { gain }(\mathrm{g})\end{array}$ & $\begin{array}{l}\text { Percentage weight } \\
\text { loss/gain (\%) }\end{array}$ \\
\hline \multicolumn{6}{|l|}{$400 \mathrm{mg}$} \\
\hline 24 hours & 2.5 & 22.3 & 23 & 0.7 & 3.14 \\
\hline 48 hours & 1.68 & 22.3 & 22.3 & 0 & 0 \\
\hline 72 hours & 4.55 & 22.3 & 21 & -1.3 & -5.83 \\
\hline 96 hours & 10.98 & 22.3 & 21.3 & -1 & -4.48 \\
\hline \multicolumn{6}{|l|}{$600 \mathrm{mg}$} \\
\hline 24 hours & 1.98 & 22 & 21 & -1 & -4.55 \\
\hline 48 hours & 0.9 & 22 & 20 & -2 & -9.09 \\
\hline 72 hours & 0.96 & 22 & 20 & -2 & -9.09 \\
\hline 96 hours & 2.88 & 22 & 21.3 & -0.07 & -3.18 \\
\hline \multicolumn{6}{|l|}{$800 \mathrm{mg}$} \\
\hline 24 hours & 1.62 & 20.3 & 19.3 & -1 & -4.93 \\
\hline 48 hours & 1.94 & 20.3 & 18.6 & -1.7 & -8.37 \\
\hline 72 hours & 0.41 & 20.3 & 17.6 & -2.7 & -13.3 \\
\hline 96 hours & 6.08 & 20.3 & 18.5 & -1.8 & -8.87 \\
\hline \multicolumn{6}{|l|}{ Chloroquine } \\
\hline 24 hours & 0.06 & 21.7 & 19.6 & -2.1 & -9.68 \\
\hline 48 hours & 0 & 21.7 & 21.3 & -0.4 & -1.84 \\
\hline 72 hours & 0 & 21.7 & 21.3 & -0.4 & -1.84 \\
\hline 96 hours & 0 & 21.7 & 21.6 & -0.1 & -0.46 \\
\hline \multicolumn{6}{|l|}{ Infected Untreated } \\
\hline 24 hours & 5.35 & 19.3 & 17 & -2.3 & -11.92 \\
\hline 48 hours & 13.34 & 19.3 & 17.6 & -1.7 & -8.81 \\
\hline 72 hours & 4.56 & 19.3 & 18 & -1.3 & -6.74 \\
\hline 96 hours & 9.5 & 19.3 & 17.3 & -2 & -10.36 \\
\hline
\end{tabular}

${ }^{+}$sign indicates weight gained while - sign indicates weight loss

Table 4: Percentage effectiveness of $V$. amygdalina at 24 hours interval.

\begin{tabular}{|l|l|l|l|l|}
\hline $\begin{array}{l}\text { Treatment of infected } \\
\text { mice }\end{array}$ & $\begin{array}{l}\text { Percentage } \\
\text { effectiveness at } 24 \\
\text { hours (\%) }\end{array}$ & $\begin{array}{l}\text { Percentage } \\
\text { effectiveness at 48 } \\
\text { hours (\%) }\end{array}$ & $\begin{array}{l}\text { Percentage } \\
\text { effectiveness at 72 } \\
\text { hours (\%) }\end{array}$ & $\begin{array}{l}\text { Percentage } \\
\text { effectiveness at 96 } \\
\text { hours (\%) }\end{array}$ \\
\hline $\mathbf{4 0 0} \mathbf{~} \mathbf{~ g / k g}$ & 54.5 & 69.5 & 72 & 82 \\
\hline $\mathbf{6 0 0} \mathbf{~ m g / k g}$ & 38.1 & 70 & 86.5 & 86.5 \\
\hline $\mathbf{8 0 0} \mathbf{~ m g / k g}$ & 71.2 & 76 & 94 & 94 \\
\hline Chloroquine $\mathbf{1 0} \mathbf{~ m g / k g}$ & 93.1 & 100 & 100 & 100 \\
\hline
\end{tabular}

body weight at $48 \mathrm{hrs}$ of administration. None of the doses of the plant extract could completely eliminate the erythrocytic stages of the parasite in the mice. The highest percentage effectiveness (94\%) of the plant extract was observed when $800 \mathrm{mg} / \mathrm{kg}$ of $V$. amygdalina was administered in vivo to the mice for $72 \mathrm{hrs}$. Generally, it was noted that the percentage effectiveness of the plant extract increases as the dose and hours of exposure increase. It was noted that at $96 \mathrm{hrs}$ of treatment with the plant extract at $400 \mathrm{mg} / \mathrm{kg}, 600 \mathrm{mg} / \mathrm{kg}$ and $800 \mathrm{mg} / \mathrm{kg}$ recorded percentage effectiveness of $82 \%, 86.5 \%$ and $94 \%$ respectively. The least percentage effectiveness (38.1\%) was observed in mice treated with $600 \mathrm{mg} / \mathrm{kg}$ V. amygdalina extract for $24 \mathrm{hrs}$.

\section{Percentage parasitemia at $\mathbf{2 4}$ hours interval}

The results as presented in Figure 1 showed the percentage parasitemia at 24 hours interval. It was observed that the infected untreated (control) group had the highest parasitemia (13.34\%) because no treatment was administered to the mice in this group. Meanwhile, the mice treated with chloroquine at $10 \mathrm{mg} / \mathrm{kg}$ had the least percentage parasitemia (0.06\%) which indicated that the standard drug chloroquine has the highest antiplasmodial activity $(0.00 \%)$ on the mice when compared to the plant extract. 


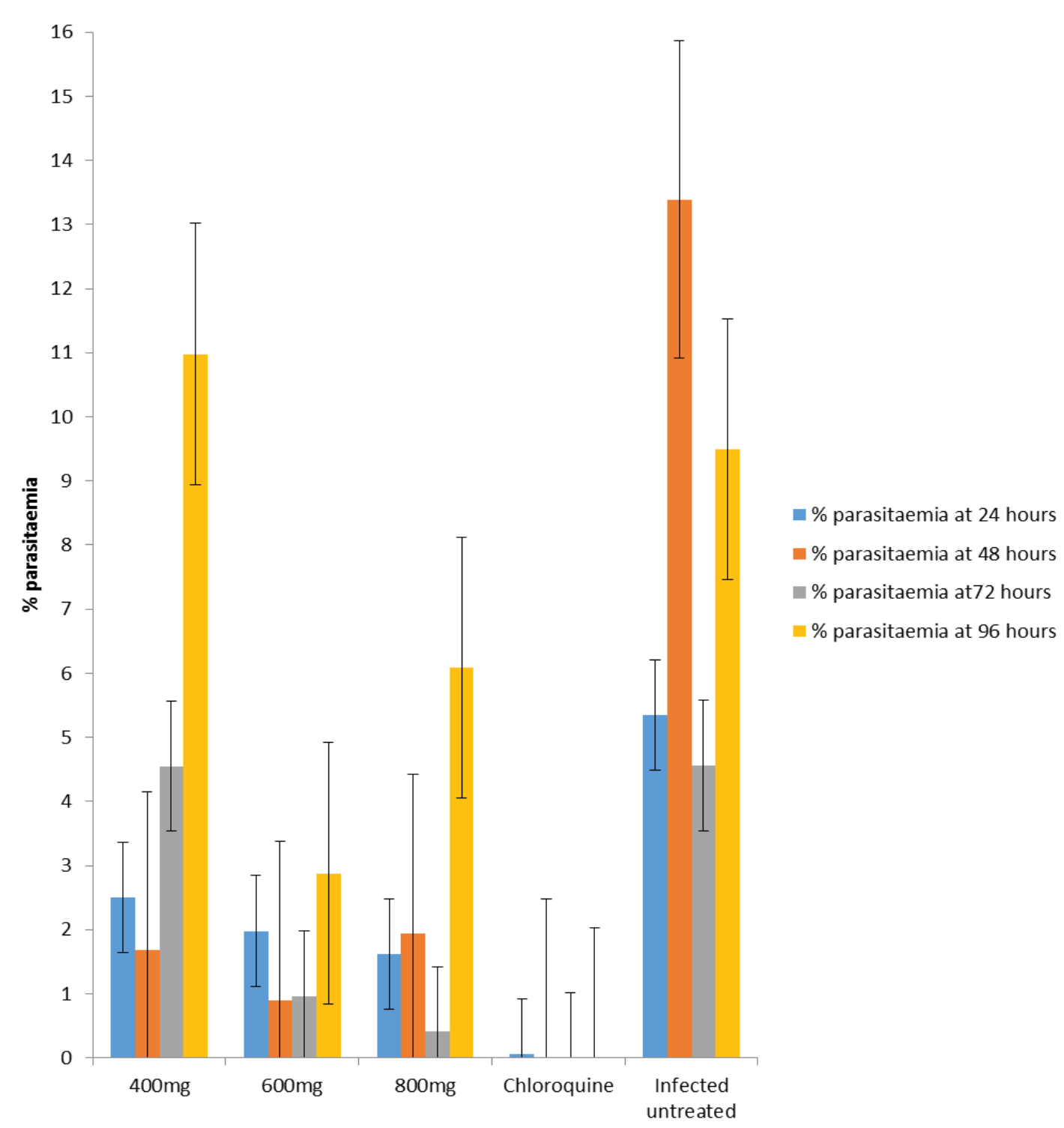

Figure 1: A bar chart showing percentage parasitemia in the mice intraperitoneally exposed to different doses of the $V$. amygdalina extract and $10 \mathrm{mg} / \mathrm{kg}$ of chloroquine at 24 hours interval.

\section{Discussion}

Plasmodium berghei parasite is used in predicting treatment outcomes of any suspected antimalarial agent due to its high sensitivity to chloroquine making it the appropriate parasite for the study. The infusion and ethanolic extract of $V$. amygdalina were effective at different dosage levels used in the treatment of the mice infected with $P$. berghei. This study shows an increase curative effect of $V$. amygdalina with the values of $82 \%$, $86.5 \%$, and $94 \%$ of ethanolic leaf extract at dosage levels of $400 \mathrm{mg} / \mathrm{kg}, 600 \mathrm{mg} / \mathrm{kg}$ and $800 \mathrm{mg} / \mathrm{kg}$ respectively. The curative anti-plasmodial test indicated that the mice treated with $V$. amygdalina at graded doses of 400,600 and $800 \mathrm{mg} / \mathrm{kg}$ body weight and chloroquine at $10 \mathrm{mg} / \mathrm{kg}$ resulted in reduced parasite load compared to negative control group. The plant extract showed no significant difference $(p>0.05)$ against $P$. berghei in mice treated at all dosage levels from 24 hours to 96 hours of treatment compared to the mice in the infected control group.
The curative anti-plasmodial activity of $V$. amygdalina and chloroquine at $10 \mathrm{mg} / \mathrm{kg}$ body weight from this study shows that chloroquine, the standard drug cleared the parasites by $100 \%$ compared to the percentage of clearance by $V$. amygdalina extract which varies at graded doses of 400,600 and $800 \mathrm{mg} / \mathrm{kg}$ against $P$. berghei infection. The in-vivo study further showed that the efficacy of the plant extract increases as dose increased from $400 \mathrm{mg} / \mathrm{kg}$ to $800 \mathrm{mg} / \mathrm{kg}$, thus the 800 $\mathrm{mg} / \mathrm{kg}$ dose had the highest efficacy than 600 and 400 $\mathrm{mg} / \mathrm{kg}$ doses. However the standard drug (chloroquine) produced the highest efficacy. This shows that optimum antiplasmodial activity (94\%) of $V$. amygdalina was recorded at $800 \mathrm{mg} / \mathrm{kg}$ while the least antiplasmodial activity (38.1\%) was recorded at $600 \mathrm{mg} / \mathrm{kg}$. the antiplasmodial activity of the dose also increases as time of administration increases. The antiplasmodial activity of $V$. amygdalina observed in this research is similar to the reports of other authors. Temesgen [18] and Temesgen, et al. [19]. The authors reported that $V$. amygdalina has 
the potency of reducing the $P$. berghei in mice and the antiplasmodial potency of the plant is associated with increased parasite suppression. Also, Omoregie, et al. [15] also reported that the ethanolic extract of $V$. amygdalina leaves showed highest antiplasmodial activity of $82.3 \%$ at $1000 \mathrm{mg} / \mathrm{kg}$. The antiplasmodial activity (82$94 \%$ ) of $V$. amygdalina recorded in this study is slightly higher to the report of Abosi and Raseroka [13], and Temesgen, et al. [19] who reported that the ethanolic leaf extracts of $V$. amygdalina suppressed parasites by $67 \%$ and $37.67 \%$ respectively. The results of the present research further reaffirmed that infection with $P$. berghei resulted into weight loss which may take few days to recover from even after therapy. Weight loss was observed in all treated mice except mice treated with $400 \mathrm{mg} / \mathrm{kg}$ for $24-48$ hours. This body weight as a result of parasitemia concurs with the report of Zemicheal and Mekonnen [20] who reported that there was decrease in body weight of mice treated with $200 \mathrm{mg} /$ $\mathrm{kg}, 400 \mathrm{mg} / \mathrm{kg}$ and $600 \mathrm{mg} / \mathrm{kg}$ from 27.74 to $25.66 \mathrm{~g}$, 29.08 to $28.88 \mathrm{~g}$ and 29.62 to $28.46 \mathrm{~g}$ respectively. The antimalarial activity of the leaf extract of $V$. amygdalina in this research work might be due to the presence of bioactive secondary metabolites contained in the plant such as terpenoids, alkaloids, phenols, flavonoids and tannins [21].

\section{Conclusion}

The results obtained from the current study indicated that $V$. amygdalina has high curative effect at the highest dose $(800 \mathrm{mg} / \mathrm{kg})$ administered to the experimental mice. The study further shows that the ethanolic leaf extract of $V$. amygdalina showed antimalarial effects, thus has the ability to drastically reduce the erythrocytic stages (merozoites, schizonts and gametocytes) of $P$. berghei. Hence, justify its traditional usage as malaria remedy. However, the dosages should be regulated. In addition, the plant extract produced significant parasitemia curative effect in dose dependent manner during 96 hours of treatment. In general, antimalarial activities further affirm the claim by traditional practitioners that the plant is effective in the treatment of malaria and support the ethnobotanical use of the plant in the treatment of malaria in Africa. Therefore, it is recommended that individuals especially in tropical Africa should develop the habit of including bitter leaf ( $V$. amygdalina) in their culinary practices in order to reduce the morbidity and mortality associated with malaria infection in the endemic areas.

\section{Acknowledgements}

The authors are grateful to Mrs. Thomas of the Institute of Advanced Medical Research and Training (IAMRAT) University College Hospital, University of Ibadan for providing technical support during the laboratory work. The technical support provided by Mrs. ET. Ojo during the plant extraction using Soxhlet machine is also appreciated.

\section{Authors' Contributions}

OJA conceived the title and designed the experimental layout. OJA and JLO carried out the laboratory experiments. JLO wrote the first draft of the manuscript and did the statistical analysis; OJA read and improved on the manuscript; OJA prepared the manuscript for publication.

\section{Funding}

This is research is self-sponsored and no funding whatsoever was received.

\section{Availability of Data and Materials}

Research data and materials can be provided on request.

\section{Competing Interests}

The authors declare that they have no competing interest.

\section{References}

1. Moss WJ, Shah SN, Morrow RH (2008) The history of malaria and its control. Johns Hopkins Bloomberg School of Public Health. Elsevier Journal 5: 389-398.

2. (2013) World Malaria Report. World Health Organization, Geneva.

3. (2019) World Malaria Report. World Health Organization, Geneva

4. Sirima SB, Sawadogo R, Moran AC, Konate A, Diarra A, et al. (2003) Failure of a chloroquine chemoprophylaxis program to adequately prevent malaria during pregnancy in Koupela District, Burkina Faso. Clin Infect Dis 36: 13741382.

5. Olliaro PL, Taylor WRJ (2003) Antimalarial compounds: From bench to bedside. J Exp Biol 206: 3753-3759.

6. Mutabingwa TK (2003) Treating malaria during pregnancy in Africa. Postgraduate Doctor Africa 25: 66-73.

7. Kaushansky A, Mikola, Czak SA, Vignali M, Kappe SH (2014) Of men in mice: The success and promise of humanized mouse model for human malaria parasite infections. Cell Microbiol 16: 602-611.

8. Beignon AS, Le Grand R, Chapon C (2014) In-vivo imaging in NHP models of malaria: Challenges, progress and outlooks. Parasitol Int 63: 206-215.

9. Donelly AV, Jason CW, Petr JS (2001) Reversal of chloroquine resistance in Plasmodium falciparum using combinations of chemosentizers. Antimicrob Agents Chemother 45: 3171-3174.

10. Tona L, Cimanga RK, Mesia K, Musuamba CT, De Bruyne $\mathrm{T}$, et al. (2004) In-vitro antiplasmodic activity of extracts and fractions from seven medicinal plants used in the Democratic Republic of Congo. J Ethnopharmacol 93: 27-32.

11. Vicki AF, Alfonso S, Tod FS, Harold R (2009) Classification of Compositae. The International Compositae Alliance.

12. Farombi EO (2003) African indigenous plants with chemotherapeutic potentials and biotechnological approach to the production of bioactive prophylactic agents. African Journal of Biotechnology 2: 662-671. 
13. Abosi AO, Raseroka BH (2003) In-vivo antimalarial activity of Vernonia amygdalina. Br J Biomed Sci 60: 89-91.

14. Massaba SC (2000) The antimalarial activity of Vernonia amygdalina Del (Compositae). Trans R Soc Trop Med Hyg 94: 694-695.

15. Omoregie ES, Pal A, Darokar MP, Chanda D, Sisodia B (2010) In-vitro and in-vivo antiplasmodial activity and cytotoxicity of extracts from Vernonia amygdalina Del. Leaves. Malaria Journal 9: 30-33.

16. (2011) Guide for the care and use of laboratory animal. National Research Council, ( $8^{\text {th }}$ edn), The National Academies Press, Washington, DC.

17. Afolabi OJ, Abejide AE (2020) Antiplasmodial activities of Morinda lucida (Benth) and Alstonia boonei (De wild) in mice infected with Plasmodium berghei. Bulletin of the National Research Centre 44: 85.
18. Temesgen B (2015) In-vivo Anti-malarial evaluation of leaf extract of Vernonia amygdalina Del. (Asteraceae) against Plasmodium berghei. Journal of Addis Ababa University 3: 1-104.

19. Temesgen B, Mirutse G, Getnet $Y$, Abebe A, Mekonnens (2019) Antimalarial activity of hydromethanolic extract and its solvent fractions of Vernonia amygdalina leaves in mice infected with Plasmodium berghei. SAGE Open Medicine 7.

20. Zemichael G, Mekonnen Y (2018) Antiplasmodial activity of Vernonia adoensis aqueous, methanol and chloroform extracts against chloroquine sensitive strain of Plasmodium berghei in-vivo in mice. BMC Research Notes 11: 736-739.

21. Toyang NJ, Verpoorte R (2013) A review of the medicinal potentials of plants of the genus Vernonia (Asteraceae). $J$ Ethnopharmacol 146: 681-723. 